\title{
Record of the Climatic Variability and the Sedimentary Dynamics during the Last Two Millennia at Sebkha Dkhila, Eastern Tunisia
}

\author{
Elhoucine Essefi, ${ }^{1,2}$ Jamel Touir, ${ }^{3,4}$ Mohamed Ali Tagorti, ${ }^{5}$ and Chokri Yaich ${ }^{1,2}$ \\ ${ }^{1}$ National Engineering School of Sfax, University of Sfax, Road of Soukra, km 4, 3038 Sfax, Tunisia \\ ${ }^{2} R U$ : Sedimentary Dynamics and Environment (DSE) (Code 03/UR/10-03), National Engineering School of Sfax, \\ University of Sfax, Sfax, Tunisia \\ ${ }^{3}$ Laboratory of Water Energy and Environment, National Engineering School of Sfax, University of Sfax, Sfax, Tunisia \\ ${ }^{4}$ Faculty of Sciences of Sfax, University of Sfax, Road of Soukra, km 4, 3038 Sfax, Tunisia \\ ${ }^{5}$ Higher Institute of Biotechnology of Monastir, Tahar Haded Avenue, University of Monastir, \\ Road Sallem Bechir, BP n56, 5000 Monastir, Tunisia
}

Correspondence should be addressed to Elhoucine Essefi; hocinsefi@yahoo.fr

Received 9 April 2013; Accepted 26 May 2013

Academic Editors: J. P. Suc and Q. Xu

Copyright (C) 2013 Elhoucine Essefi et al. This is an open access article distributed under the Creative Commons Attribution License, which permits unrestricted use, distribution, and reproduction in any medium, provided the original work is properly cited.

\begin{abstract}
This paper aimed to study the record of the climatic variability during the last two millennia within the sebkha of Dkhila. Six climatic stages were recognized along the $104 \mathrm{~cm}$ core: the Warming Present (WP), the Late Little Ice Age (Late LIA), the Early Little Ice Age (ELIA), the Medieval Climatic Anomaly (MCA), the Dark Age (DA), and the Roman Warm Period (RWP). The WP stretches along the uppermost $1 \mathrm{~cm}$ with a high grey scale as sign of a dry climate. The Late LIA is located between $1 \mathrm{~cm}$ and $6 \mathrm{~cm}$. The ELIA is located between $6 \mathrm{~cm}$ and $40 \mathrm{~cm}$. The MCA spanning from $40 \mathrm{~cm}$ to $72 \mathrm{~cm}$ is marked by a sharp increase of the GS revealing a wet period. The DA appears along the part between $72 \mathrm{~cm}$ and $84 \mathrm{~cm}$; a shift from light to dark sediments is recorded. The RWP appears between $84 \mathrm{~cm}$ and $104 \mathrm{~cm}$. Based on the grain size distribution, two low frequency cycles were identified indicating radical global changes of climatic conditions, the differential tectonics, and the groundwater fluctuations. On the other hand, high frequency cycles indicate local modifications of the climatic conditions.
\end{abstract}

\section{Introduction}

It was previously proven [1-4] that the sebkha Dkhila (as part of the sebkha Sidi El Hani) is dominated by a hydrogeological basin feeding this depression by salty water. Consequently, the hydrogeological context remains stable regardless of the climatic change. In such a case, the playa would not record the climatic variability because the high salinity imposed by coming up of saline water does not radically change with respect to climatic changes. At the level of the watershed surrounding the depression, previous investigations [5] showed the outcrop of wet aeolian sediments mainly dominated by groundwater involvement rather than the climatic variability. Subsequently, it is not evident to find an obvious record of climate changes within the watershed. The aim in this paper is to overcome these handicaps and to infer the climatic variability during the last two millennia based on the visual description of cores, the magnetic properties, and the grainsize distribution.

\section{Study Area}

The sebkha of Dkhila is part of the sebkha of Sidi El Hani, which is in turn part of the system Mechertate-Chrita-Sidi El Hani. Though it has always been treated as a single unit, the sebkha of Sidi El Hani as such is actually made up of three communicated playas; from north to the south, one finds the playas of Sidi El Hani (sensu stricto), of Souassi Sou, and of Dkhila (Figure 1). The sebkha of Mhabeul is located in the southeast of Tunisia (Figure 1). It is an inland saline environment located in southeast Tunisia (Figure 1). Based on a $65 \mathrm{~cm}$ core, it was used by Marquer et al. [6] to infer 


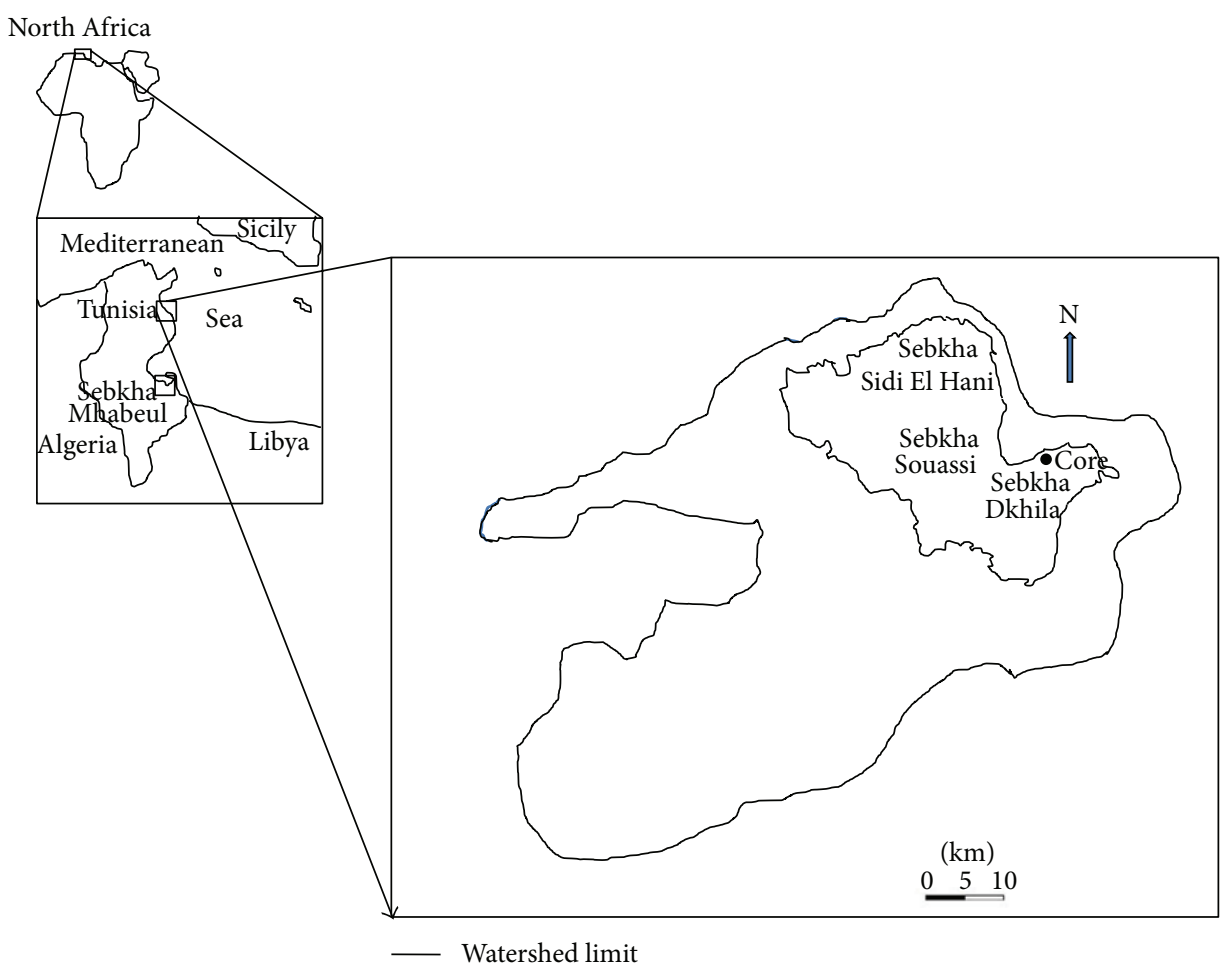

FIGURE 1: Geographical location of sebkhas Dkhila and Mhabeul.

the climatic variability during the last two millennia. Since it is the only known sebkha of which we have the record of the climatic variability during the last millennia, this sebkha serves as reference to find out the major climatic events in the sebkha Dkhila.

\section{Methods and Materials}

Coring technique proves efficient to study the sedimentary dynamics and the record of the climatic variability $[1,7]$. In the laboratory, cores underwent nondestructive and destructive analyses.

The sediment darkness is a result of a high ratio of the organic matter content, which reflects high degree of confinement. As it was used by Marquer et al. [6], an arbitrary method was used in this study to evaluate this darkness on the basis of the grey scale (GS). Minimum greyscale values are associated with high magnitude flood. This could characterize periods with high frequency of intense precipitation events, most probably during the wet seasons. Maximum grey-scale values are associated with more stable climatic conditions, marked by flood events of lower magnitude or lower-frequency scale. The evaluation of darkness needed software of image treatment because minor grey-scale variability could be detected only by such a sophistication (e.g., [6]). But, in the case of the Dkhila core, only visual method was used; consequently, it was more convenient to speak about the major grey-scale variability. Since we have been paving the way for comparison between the sebkha Dkhila core and the sebkha Mhabeul one, the minor grey scale detected by software in sebkha Mhabeul core had to be converted to the major grey scale detected by the naked eye.
Wet process analyses were carried out by the FRITSCH laser grain-size analyzer. Then, the descriptive grain-size distribution was carried out based on the ternary diagram sand/silt/clay of Shepard [8]. The core was also investigated in terms of genetic grain-size distribution. This investigation distinguished between the aeolian, the geochemical, and the hydraulic sedimentations based on modes of the grain-size distribution [1, 9-12]. Sun et al. [9] considered the fraction centered around $6 \mu \mathrm{m}$ as fine aeolian component and the fraction centered around $60 \mu \mathrm{m}$ as coarse aeolian component, whereas the coarse hydraulic component is centered around $380 \mu \mathrm{m}$ and the fine hydraulic fraction is centered around $1 \mu \mathrm{m}$. Based on their cumulative curves, Cailleux and Tricart [13] distinguished between 23 types of sedimentation: six estuary and deltaic, seven marine, two glacial, three aeolian, and five fluvial types. Added to the traditional sand/silt/clay subdivision used in the literature, Manté et al. [11] coined the term colloids as the fraction between $0.063 \mu \mathrm{m}$ and $1 \mu \mathrm{m}$. This fraction is of a geochemical origin. Grain-size components of aeolian deposits depend on the nature of winds (i.e., high- and low-altitude air flows and near-ground winds) and transport distances (long or short distance) $[9,14,15]$. Based on the method of features of Allen and Haslett [10], the descriptive classification of Flemming [16] and the three reference cumulative curves of aeolian types (their transformation toward frequency curves) discussed by Cailleux and Tricart [13] and Essefi [1] distinguished between three types of aeolian sediments. First, the aeolian sand could be transported by strong wind. Its most important features are the mode at $500 \mu \mathrm{m}$ and the two shoulders at $250 \mu \mathrm{m}$ and $1600 \mu \mathrm{m}$. Consequently, this aeolian sediment is classified according to sand/silt/clay diagram of Flemming [16] as 


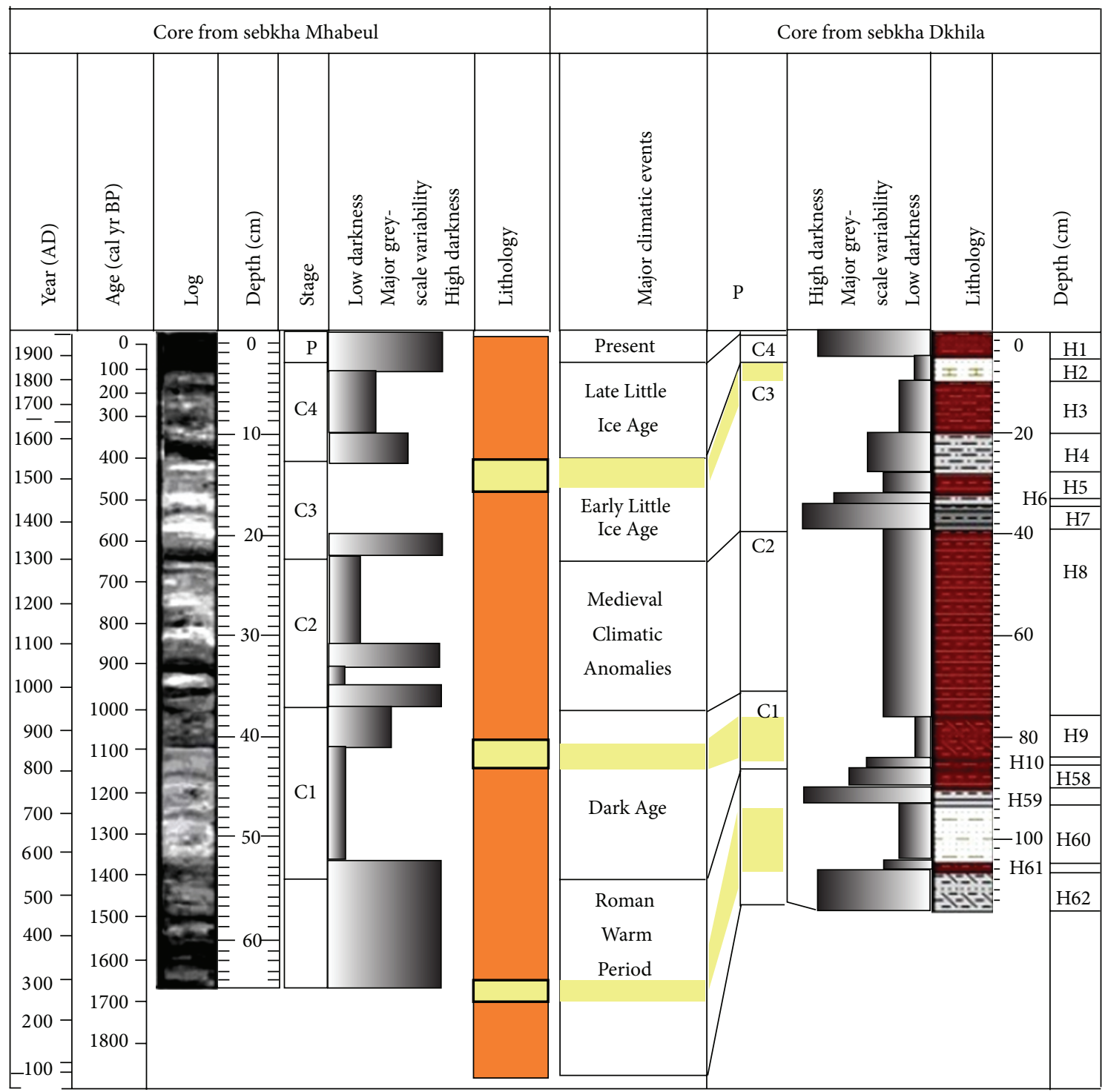

Sandy sedimentation

Clayey sedimentation

FIGURE 2: Correlation between sebkhas Mhabeul and Dkhila based on the gray-scale variability and three sandy reference bands.

sand. Second, the slightly silty aeolian sand [16] could be transported by a moderate wind. The most important features are the mode at $315 \mu \mathrm{m}$ and the two shoulders at $200 \mu \mathrm{m}$ and $800 \mu \mathrm{m}$. Third, the silty aeolian sand [16] could be transported by calm wind. The most apparent features are the mode at $160 \mu \mathrm{m}$ and the two shoulders at $250 \mu \mathrm{m}$ and $1000 \mu \mathrm{m}$. To conclude, the fractions centered around 6, 60 [9], 160, 315, and $500 \mu \mathrm{m} \mathrm{[1]} \mathrm{mark} \mathrm{the} \mathrm{aeolian} \mathrm{component.} \mathrm{The} \mathrm{hydraulic}$ component is marked by the fractions $1 \mu \mathrm{m}$ and $380 \mu \mathrm{m}$ [9]. The geochemical fraction is marked by colloids, which are smaller than $1 \mu \mathrm{m}$ [11].

The magnetic susceptibility was measured by the Bartington MS2B probe in the laboratory of Sedimentary Dynamics and Environment, National engineering School of Sfax, at a frequency of $0.47 \mathrm{kHz}$. The use of the magnetic susceptibility is twofold. On the one hand, it allows the detection of high magnetic signature probably related to tephra layers, which may serve in dating the core. The use of magnetic susceptibility in tephrostratigraphy was recently discussed by Essefi et al. [17]. On the other hand, it may have a climatic or sedimentary significance.

\section{Results}

4.1. Correlation between Sebkhas Mhabeul and Dkhila. The correlation between core $(104 \mathrm{~cm})$ from sebkha Dkhila and a core from sebkha Mhabeul $(65 \mathrm{~cm})$ (Figure 2) shows that the climatic variability recorded during the last two millennia in $65 \mathrm{~cm}$ is recorded in core of sebkha Dkhila in $104 \mathrm{~cm}$. The rate of sedimentation is higher in this location of sebkha Dkhila 


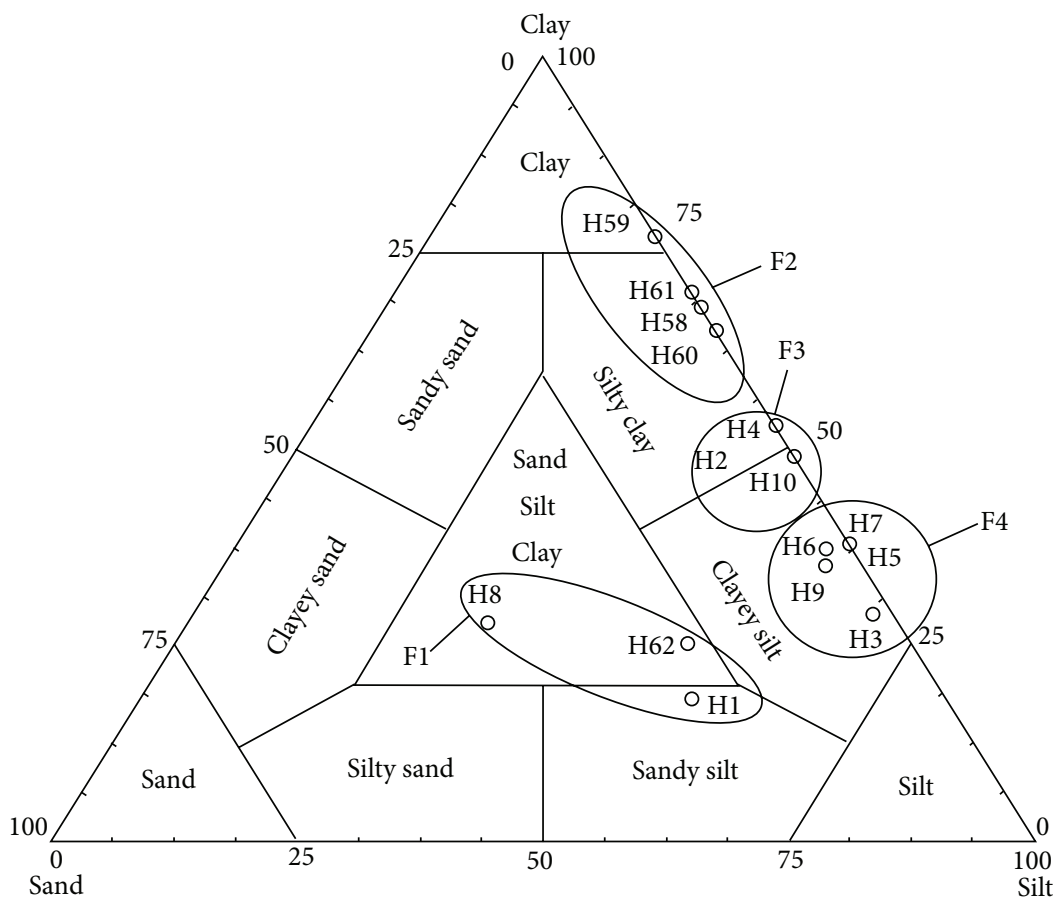

FIgURE 3: Samples of the core from sebkha Dkhila within the ternary diagram of Shepard [8].

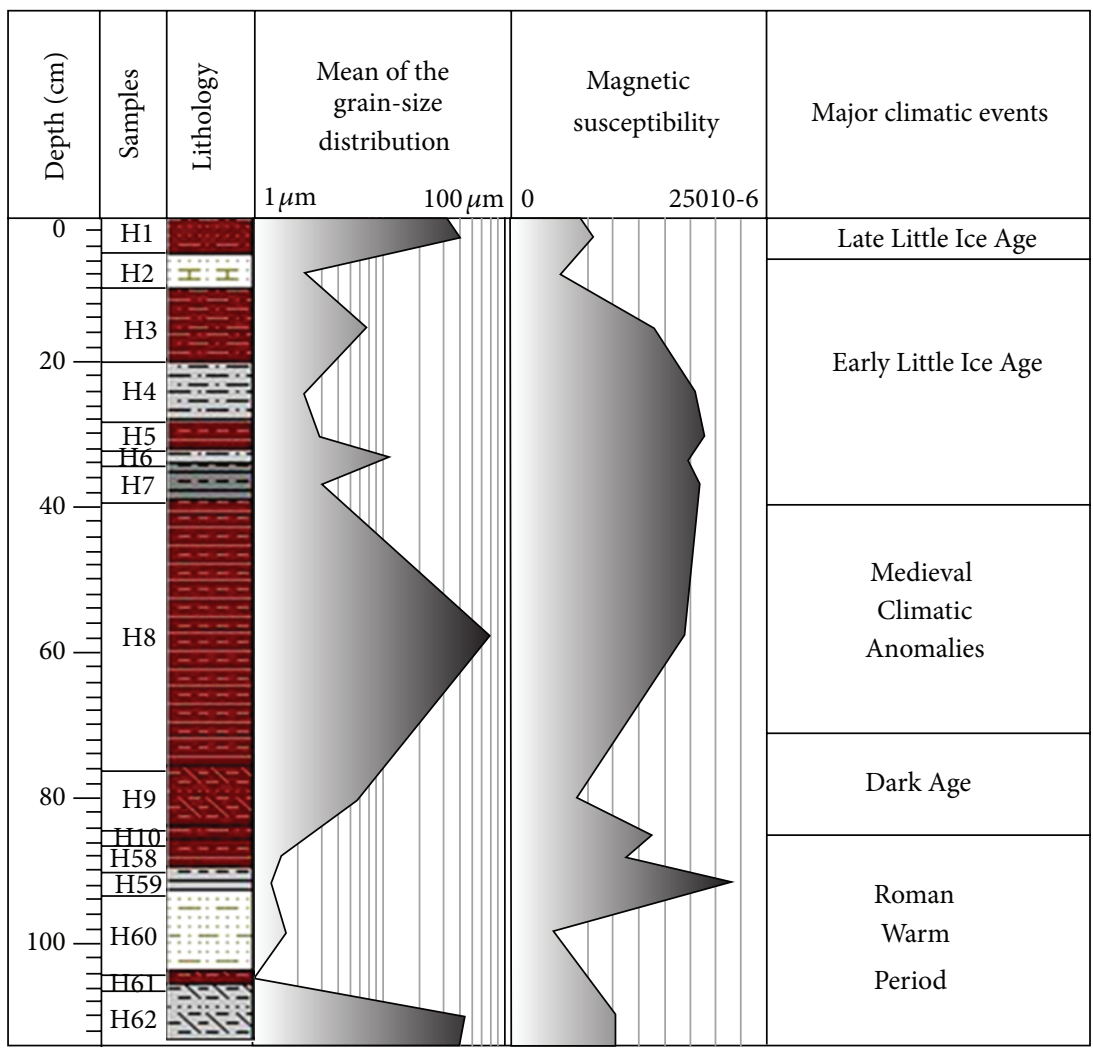

FIGURE 4: Mean of the grain size distribution, magnetic susceptibility, and cyclostratigraphy along the core of sebkha Dkhila. 


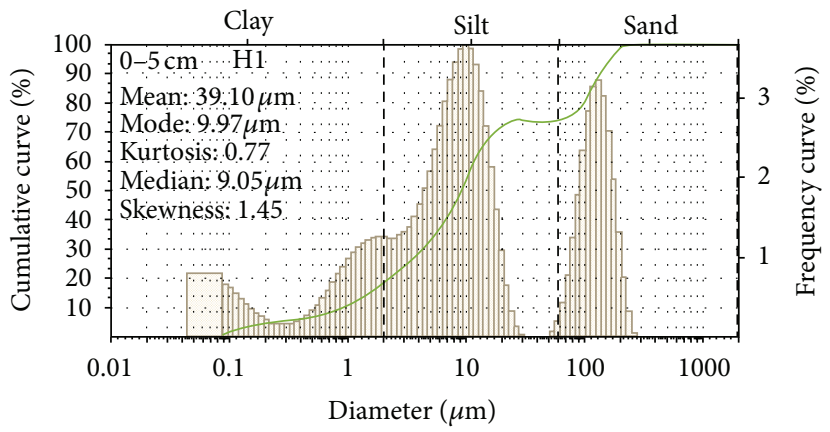

FIGURE 5: Grain-size distribution of the WP and the Late LIA along the core from sebkha Dkhila.

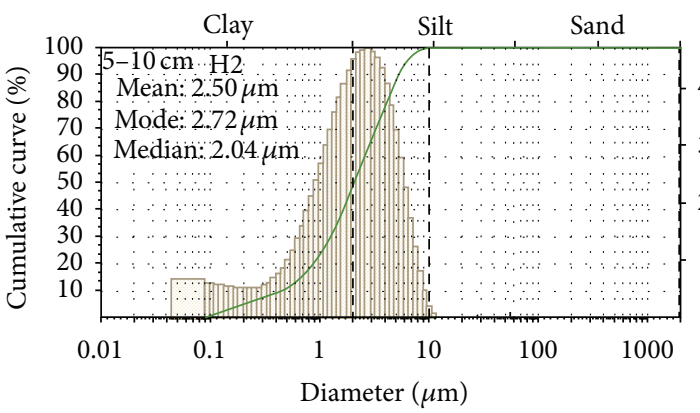

(a)

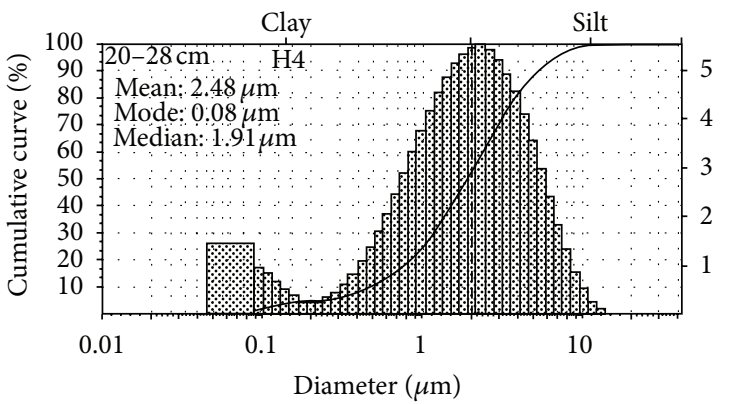

(c)

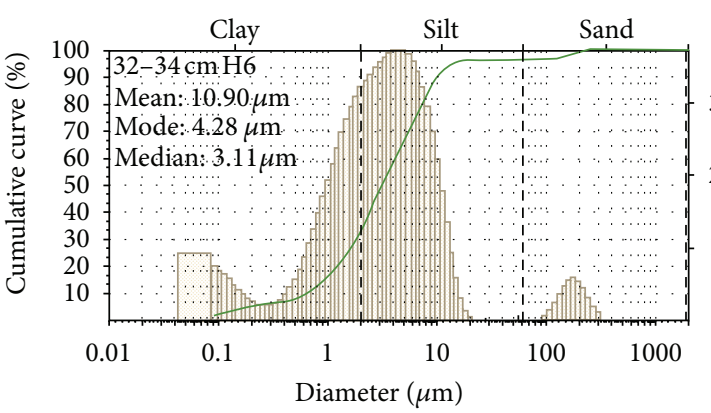

(e)

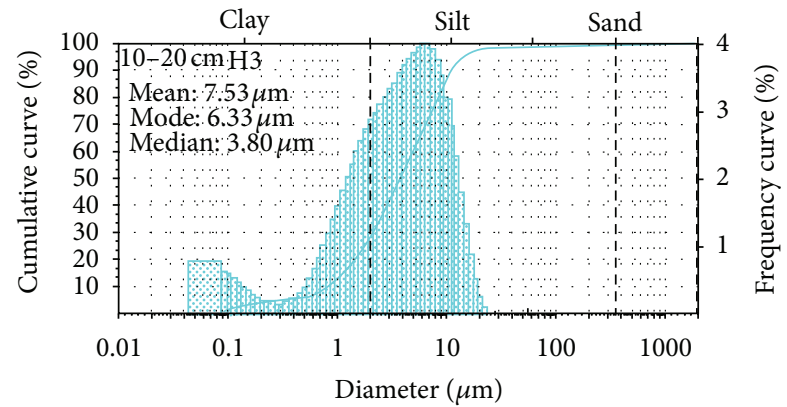

(b)

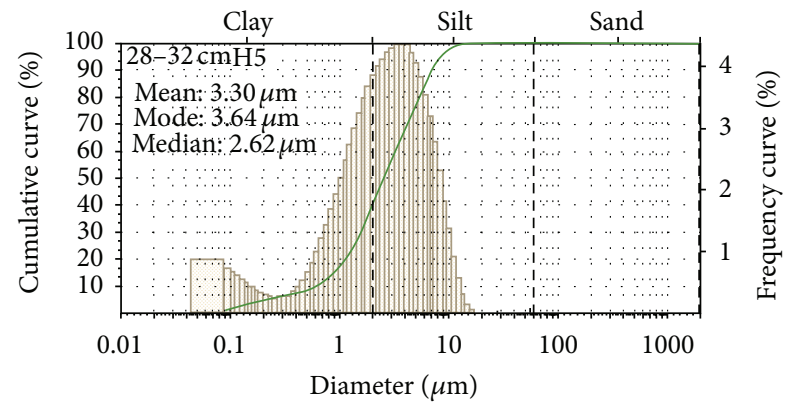

(d)

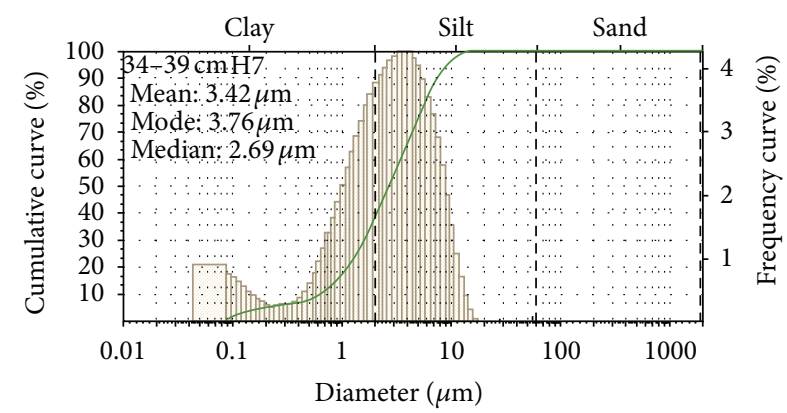

(f)

FIgURE 6: Grain-size distribution of the Early Little Ice Agealong the core from sebkha Dkhila.

than in sebkha Mhabeul. By following the major grey-scale variability and the three reference bands along both cores, the six climatic stages recognized in sebkha Mhabeul were also found out along the core of sebkha Dkhila. First, the Warming Present (WP) stretches along the uppermost $1 \mathrm{~cm}$ with its high grey scale as sign of a dry climate. Second, the Late Little Ice Age (Late LIA) is located between $1 \mathrm{~cm}$ and $6 \mathrm{~cm}$. As in sebkha Mhabeul core, this period is limited at the bottom by the first reference sandy band. Third, Early Little Ice Age (ELIA) is located between $6 \mathrm{~cm}$ and $40 \mathrm{~cm}$. Climatologically, the intermediate values of GS having a tendency toward increasing indicate that this stage may 


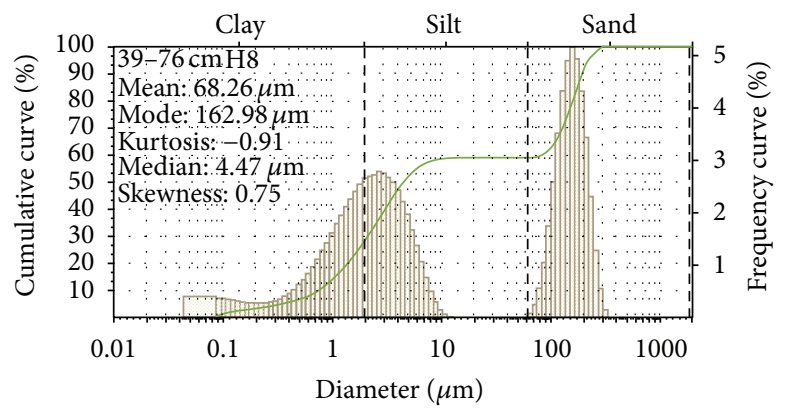

FIGURE 7: Grain-size distribution of the Medieval Climatic Anomalyalong the core from sebkha Dkhila.

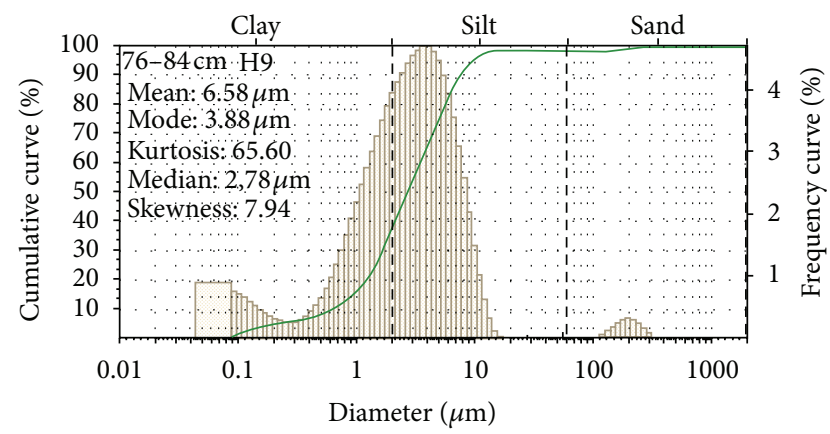

(a)

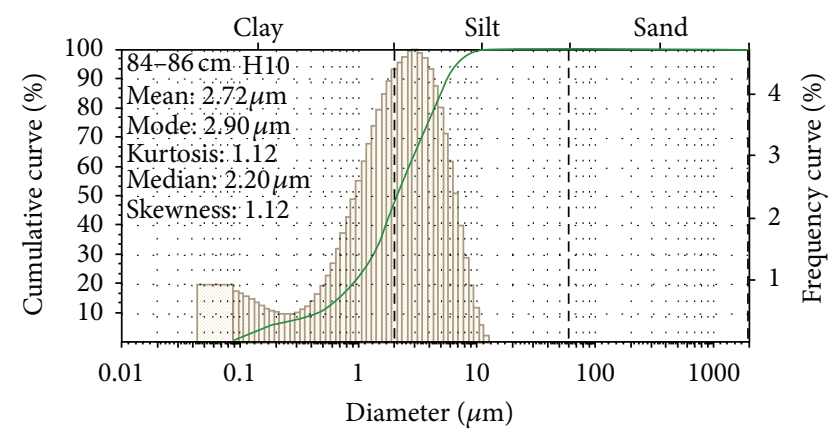

(b)

FIGURE 8: Grain-size distribution of the Dark Agealong the core from sebkha Dkhila.

be classified as moderate with a tendency toward aridity. Fourth, the Medieval Climatic Anomaly (MCA) spanning from $40 \mathrm{~cm}$ to $72 \mathrm{~cm}$ is marked by a sharp increase of the GS revealing a wet period. Fifth, Dark Age (DA) appears along the part between $72 \mathrm{~cm}$ and $84 \mathrm{~cm}$; a shift from light to dark sediments is recorded. As for the grain-size distribution, the second reference sandy band is detected in the top of the DA. Sixth, the Roman Warm Period (RWP) appears between $84 \mathrm{~cm}$ and $104 \mathrm{~cm}$. According the major grey scale, this period may be divided into substages. The first (from $84 \mathrm{~cm}$ to $94 \mathrm{~cm}$ in sebkha Dkhila core) is marked by high GS values associated with dark sediments suggesting stable climatic conditions. The second (from $94 \mathrm{~cm}$ to $104 \mathrm{~cm}$ in the sebkha Dkhila core) is marked by a third sandy reference band and low GS values as signs of wet climate.

4.2. Occurrence of Sedimentary Facies during the Climatic Stages. The descriptive grain-size distribution (Figure 3) shows the evolution of the sedimentary dynamics within the sebkha of Dkhila. The top (H1), the middle (H8), and the bottom (H62) of the core are basically a mixture facies (F1) with dominance of the sandy fraction. The second facies (F2) is basically clayey represented by the samples H58, H59, H60, and H61. The third facies (F3) is basically a mixture of silt and clay represented by the samples $\mathrm{H} 2, \mathrm{H} 4$, and H10. The fourth facies is basically silty represented by the samples H3, H5, H6, $\mathrm{H} 7$, and $\mathrm{H} 9$.

4.3. Evolution of the Genetic Grain-Size Distribution during the Climatic Stages. Based on the mean of the grain-size distribution and the magnetic susceptibility, the core of sebkha Dkhila may be subdivided into different sedimentary facies (Figure 4). These facies are the record of climatic change, groundwater fluctuations, and differential tectonics.

The same sedimentary or transportation processes usually give birth to unimodal frequency curves of grain-size distribution. When involving more than one sedimentary or transportation process and sediments with a polymodal distribution, a polymodal distribution is the sum of all kinds of sedimentary components [9, 18-23]. The aeolian deposits possess clear grain-size distribution features different from other sediments (e.g., [18, 23-27]). Most modal peaks of grain-size frequency curves of aeolian deposits in lacustrine sediments are between 10 and $100 \mu \mathrm{m}$ [19, 21, 22, 28-31]. Hence, we regard the primary modal peaks (between 10 and $100 \mu \mathrm{m}$, mode at about $40 \mu \mathrm{m}$ ) of ISL1A core samples as the aeolian component within lacustrine sediments. In arid regions, rivers with low discharge are normally not able to transport coarse particles (e.g., $>60 \mu \mathrm{m}$ ) to the central part of a lake [30, 32]. Liu et al. [21] interprets the coarsegrained materials with mode at about $35-40 \mu \mathrm{m}$ as aeolian component within lacustrine sediments in other arid and closed lakes on the QTP.

4.3.1. Warming Present (WP) and the Late Little Ice Age (Late LIA). The first facies is located at the first $5 \mathrm{~cm}$; it is sandy silt. The WP period and Little Ice Age (Late LIA) [33] expand to $400 \mathrm{yrBP}$; that is, 320 years are dominated by a sandy sedimentation. The top of the cycle (Figure 5) shows an obvious coarsening; it is characterized by a primary mode (M: ca. $10 \mu \mathrm{m})$ as an indication of the fine aeolian sedimentation. This 


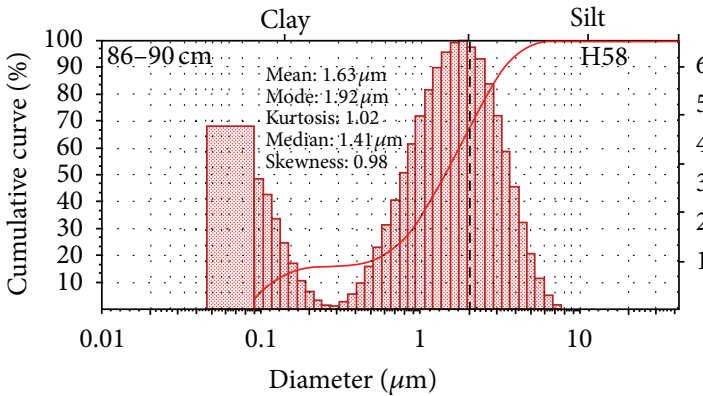

(a)

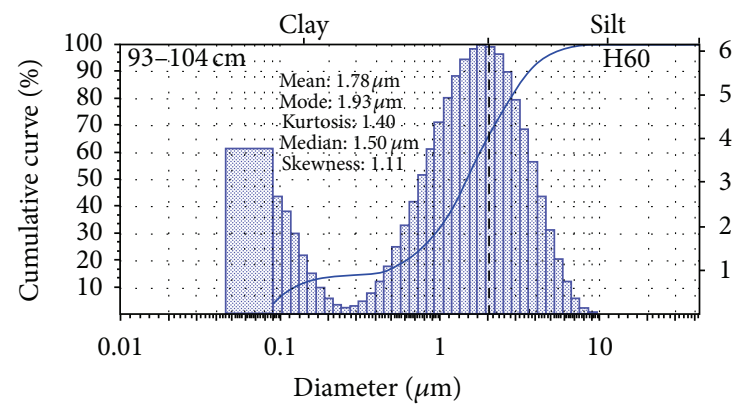

(c)

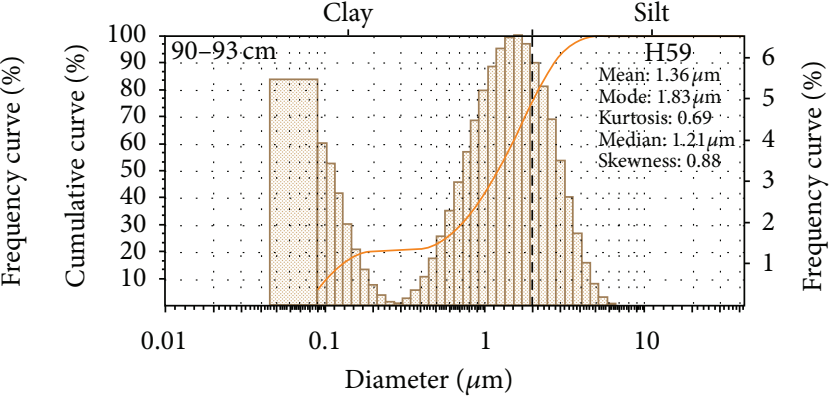

(b)

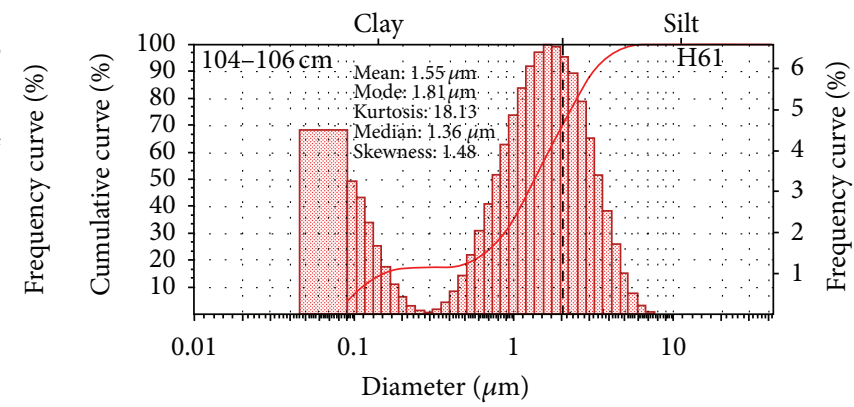

(d)

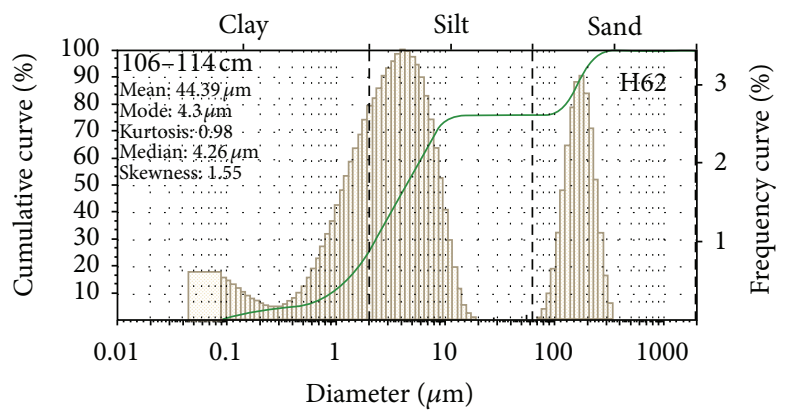

(e)

FIGURE 9: Grain-size distribution of the Roman Warm Period along the core from sebkha Dkhila.

component coincides with the silty fraction of the sample. The secondary mode $(\mathrm{m}$ : less than $140 \mu \mathrm{m})$ is an indication of the coarse aeolian sedimentation. This component coincides with the silty fraction of the sample.

4.3.2. Early Little Ice Age. The clayey samples $\mathrm{H} 2$ and $\mathrm{H} 4$ (Figures 6(a) and 6(c)) belong to the facies F3; they are expressed by a fine sedimentation (M: ca. $2.5 \mu \mathrm{m}$ ), which coincides with the minimum of accommodation. This decrease of accommodation is due to stable climatic conditions and/or water table rise. Genetically, this component is probably of hydraulic origin. However fine, $\mathrm{H} 3$ and $\mathrm{H} 6$ show a tendency towards coarsening (Figures 6(b) and 6(e)); genetically speaking, these silt facies F4 are characterized by the dominance of the fine aeolian fraction (M: ca. $6 \mu \mathrm{m}$ ) and the appearance of the coarse aeolian sedimentation (m: ca. $160 \mu \mathrm{m}$ ). It is worth noting however that, belonging to the same facies F4, H5 and $\mathrm{H} 7$ are genetically distinguished from $\mathrm{H} 3$ and $\mathrm{H} 6$. The coarse aeolian sedimentation (m: ca. $160 \mu \mathrm{m}$ ) is absent. This is one of the pitfalls of the descriptive grain-size distribution. As a matter of fact, Flemming [16] critically studied the credibility of ternary diagrams sand/silt/clay in the interpretation of sedimentary dynamics and depositional environments.

4.3.3. Medieval Climatic Anomaly (MCA). The MCA is marked by an increase of the mean of the grain-size distribution (Figure 7). The obvious coarsening with a primary mode (M: ca. $160 \mu \mathrm{m}$ ) is an indication of the coarse aeolian sedimentation and a secondary mode (m: ca. $2.5 \mu \mathrm{m}$ ) is an indication of the fine hydraulic sedimentation and an absent (A: ca. $10-100 \mu \mathrm{m}$ ). This mixture of sand/silt/clay shows a tendency toward the coarse fraction.

4.3.4. Dark Age (DA). The samples $\mathrm{H} 9$ and $\mathrm{H} 10$ are silty belonging to the facies F4 and F3, respectively. The top of this period $\mathrm{H} 9$ is coarser (Mean: $6.58 \mu \mathrm{m}$ ); it is expressed by a coarse aeolian fraction (Figure $8(\mathrm{~b})$ ). The bottom of this period becomes finer (Mean: $6.58 \mu \mathrm{m}$ ); it is characterized by a primary mode (M: ca. $2.90 \mu \mathrm{m}$ ) as indication of the fine hydraulic sedimentation. 
4.3.5. Roman Warm Period. This period shows an obvious fining (F2: H58, H59, H60, and H61) of the mean of the grainsize distribution. The clayey facies F2 is dominated by the geochemical (less than $1 \mu \mathrm{m}$ ) and hydraulic (centered around ca. $1.8 \mu \mathrm{m}$ ) fractions (Figures 9(a), 9(b), 9(c), and 9(d)). The stable climatic conditions are in favor of the sedimentation of the fine fraction.

\section{Conclusion}

The VCD was a useful tool for correlation between Dkhila cores and a core from sebkha Mhabeul in order to guess the climatic variability during the last two millennia in this clay pan. This method has permitted the guessing of the climatic variability in sebkha Dkhila during the last two millennia. The six climatic stages recognized in sebkha Mhabeul core were identified in the core of Dkhila clay pan. Furthermore, the studied core proves that sebkha Dkhila is more subsiding than sebkha Mhabeul. These climatic stages are combined with a radical change of the sedimentary dynamics detected based on the genetic study of the grain-size distribution.

\section{References}

[1] E. Essefi, Multidisciplinary study of Sidi El Hani Saline Environment: the History and the Climatic Variability [Master thesis], Faculty of sciences of Sfax, University of Sfax, 2009.

[2] E. Essefi, J. Touir, M. A. Tagorti et al., "Modeling of the chaotic behavior of Sidi El Hani discharge playa, Tunisian Sahel: which exogenous factor commands this saline environment? The subsurface flow or the climatic variability?" in Proceedings of the International Congress Geotunis, 2009.

[3] E. Essefi, J. Touir, M. A. Tagorti, and C. Yaich, "Effect of the groundwater contribution, the climatic change, and the human induced activities on the hydrological behavior of discharge playas: a case study Sidi El Hani discharge playa, Tunisian Sahel," Arabian Journal of Geoscience, 2012.

[4] M. A. Tagorti, E. Essefi, J. Touir, R. Guellala, and C. Yaich, "Geochemical controls of groundwaters upwelling in saline environments: case study the discharge playa of Sidi El Hani (Sahel, Tunisia)," African Earth Science Journal, 2013.

[5] E. Essefi, Wet aeolian sedimentology and sequence stratigraphy in Eastern Tunisia: implications for wet aeolian sedimentology and sequence stratigraphy on mars [Ph.D. thesis], National Engineering School of Sfax, 2013.

[6] L. Marquer, S. Pomel, A. Abichou, E. Schulz, D. Kaniewski, and E. Van Campo, "Late Holocene high resolution palaeoclimatic reconstruction inferred from Sebkha Mhabeul, southeast Tunisia," Quaternary Research, vol. 70, no. 2, pp. 240-250, 2008.

[7] E. Essefi, A. G. Fairén, G. Komatsu, F. Rekhiss, and C. Yaich, "Study of cores from a spring mound at the mars analog of Boujmal, eastern Tunisia: coring martian spring mounds as potential efficient tool for a geologic exploration of early Mars," 3rd Conference on Early Mars, 7029 (abstracts), 2012.

[8] F. P. Shepard, "Nomenclature based on sand-silt-clay ratios," Journal of Sedimentary Petrology, vol. 24, pp. 151-158, 1954.

[9] D. Sun, J. Bloemendal, D. K. Rea et al., "Grain-size distribution function of polymodal sediments in hydraulic and aeolian environments, and numerical partitioning of the sedimentary components," Sedimentary Geology, vol. 152, no. 3-4, pp. 263$277,2002$.
[10] J. R. L. Allen and S. K. Haslett, "Granulometric characterization and evaluation of annually banded mid-Holocene estuarine silts, Welsh Severn Estuary (UK): coastal change, sea level and climate," Quaternary Science Reviews, vol. 25, no. 13-14, pp. 14181446, 2006.

[11] C. Manté, A.-F. Yao, and C. Degiovanni, "Principal component analysis of measures, with special emphasis on grain-size curves," Computational Statistics and Data Analysis, vol. 51, no. 10, pp. 4969-4983, 2007.

[12] E. Essefi, G. Komatsu, A. G. Fairén, M. A. Chan, and C. Yaich, "Groundwater influence on the aeolian sequence stratigraphy of the Mechertate-Chrita-Sidi El Hani system, Tunisian Sahel: analogies to the wet-dry aeolian sequence stratigraphy at Meridiani Planum, Terby crater, and Gale crater, Mars," Planetary and Space Science, 2013.

[13] A. Cailleux and J. Tricart, Le modèle glaciaire et nival, SEDES, Paris, 508 pages (1967). Le modelé des régions périglaciaires, SEDES, Paris, 512 pages, 1962.

[14] K. Pye, Aeolian Dust and Dust Deposits, Academic Press, London, UK, 1987.

[15] H. Tsoar and K. Pye, "Dust transport and the question of desert loess formation," Sedimentology, vol. 34, no. 1, pp. 139-153, 1987.

[16] B. W. Flemming, "A revised textural classification of gravel-free muddy sediments on the basis of ternary diagrams," Continental Shelf Research, vol. 20, no. 10-11, pp. 1125-1137, 2000.

[17] E. Essefi, G. Komatsu, A. G. Fairén, F. Rekhiss, and C. Yaich, "Identification of tephra layers in spring mounds at the terrestrial analog of Boujmal, eastern Tunisia: repercussions and limits of tephrostratigraphy application on martian stratigraphy and paleoclimatology," 3rd Conference on Early Mars, 7034 (abstracts), 2012.

[18] A. Moreno, I. Cacho, M. Canals et al., "Saharan dust transport and high-latitude glacial climatic variability: the Alboran Sea record," Quaternary Research, vol. 58, no. 3, pp. 318-328, 2002.

[19] M. Fan, C. Song, D. L. Dettman, X. Fang, and X. Xu, "Intensification of the Asian winter monsoon after 7.4 Ma: grain-size evidence from the Linxia Basin, northeastern Tibetan Plateau, 13.1 Ma to 4.3 Ma," Earth and Planetary Science Letters, vol. 248, no. 1-2, pp. 186-197, 2006.

[20] J. Xiao, J. Wu, B. Si et al., "Holocene climate changes in the monsoon/arid transition reflected by carbon concentration in Daihai Lake of Inner Mongolia," Holocene, vol. 16, no. 4, pp. 551560, 2006.

[21] X. Liu, H. Dong, X. Yang et al., "Late Holocene forcing of the Asian winter and summer monsoon as evidenced by proxy records from the northern Qinghai-Tibetan Plateau," Earth and Planetary Science Letters, vol. 280, no. 1-4, pp. 276-284, 2009.

[22] H. Jiang and Z. Ding, "Eolian grain-size signature of the Sikouzi lacustrine sediments (Chinese Loess Plateau): implications for Neogene evolution of the East Asian winter monsoon," Bulletin of the Geological Society of America, vol. 122, no. 5-6, pp. 843854, 2010.

[23] F. An, H. Ma, H. Wei, and Z. Lai, "Distinguishing aeolian signature from lacustrine sediments of the Qaidam Basin in northeastern Qinghai-Tibetan Plateau and its palaeoclimatic implications," Aeolian Research, vol. 4, pp. 17-30, 2012.

[24] Z. T. Guo, W. F. Ruddiman, Q. Z. Hao et al., "Onset of Asian desertification by $22 \mathrm{Myr}$ ago inferred from loess deposits in China," Nature, vol. 416, no. 6877, pp. 159-163, 2002.

[25] S. L. Yang and Z. L. Ding, "Comparison of particle size characteristics of the Tertiary "red clay" and Pleistocene loess in 
the Chinese Loess Plateau: implications for origin and sources of the "red clay"', Sedimentology, vol. 51, no. 1, pp. 77-93, 2004.

[26] S. Donghuai, J. Bloemendal, D. K. Rea et al., "Bimodal grainsize distribution of Chinese loess, and its palaeoclimatic implications," Catena, vol. 55, no. 3, pp. 325-340, 2004.

[27] H. Long, N. A. Wang, H. Z. Ma, and Y. Li, "Eolian activity and environment evolution history recorded by the Qingtu Lake, NW Tengger Desert," Acta Sedimentologica Sinica, vol. 25, pp. 626-631, 2007 (Chinese).

[28] Q. L. Sun, J. Zhou, and J. L. Xiao, "Grain-size characteristics of Lake Daihai sediments and its paleoenvironment significance," Marine Geology and Quaternary Geology, vol. 21, pp. 93-95, 2001 (Chinese).

[29] L. P. Yue, L. R. Yang, Z. P. Li, M. Wang, W. J. Zhang, and H. G. Nie, "Grain-size distribution of the sediments of dry lakebed in the northwest of China and sand-dust weather in East Asia," Acta Sedimentologica Sinica, vol. 22, pp. 325-331, 2004 (Chinese).

[30] S. Xiao, F. Chen, M. Qiang, J. Zhang, A. Zhou, and D. Sun, "Distribution pattern of grain size in surface sediments from Sugan Lake and its potential in recording aeolian dust in arid China," Acta Geographica Sinica, vol. 62, no. 11, pp. 1153-1164, 2007 (Chinese).

[31] Z. Q. Yin, X. G. Qin, J. S. Wu, and B. Ning, "Multimodal grainsize distribution characteristics and formation mechanism of lake sediments," Quaternary Sciences, vol. 28, pp. 346-353, 2008 (Chinese).

[32] P. De Deckker, T. Correge, and J. Head, "Late Pleistocene record of cyclic eolian activity from tropical Australia suggesting the Younger Dryas is not an unusual climatic event," Geology, vol. 19, no. 6, pp. 602-605, 1991.

[33] G. C. Wiles, D. J. Barclay, P. E. Calkin, and T. V. Lowell, "Century to millennial-scale temperature variations for the last two thousand years indicated from glacial geologic records of Southern Alaska," Global and Planetary Change, vol. 60, no. 1-2, pp. 115-125, 2008. 

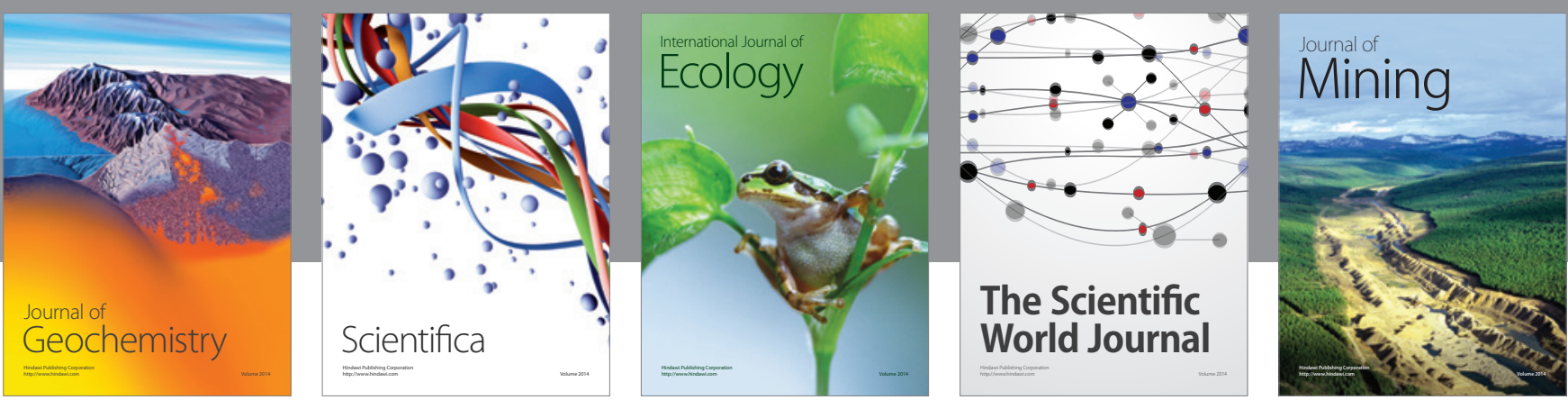

The Scientific World Journal
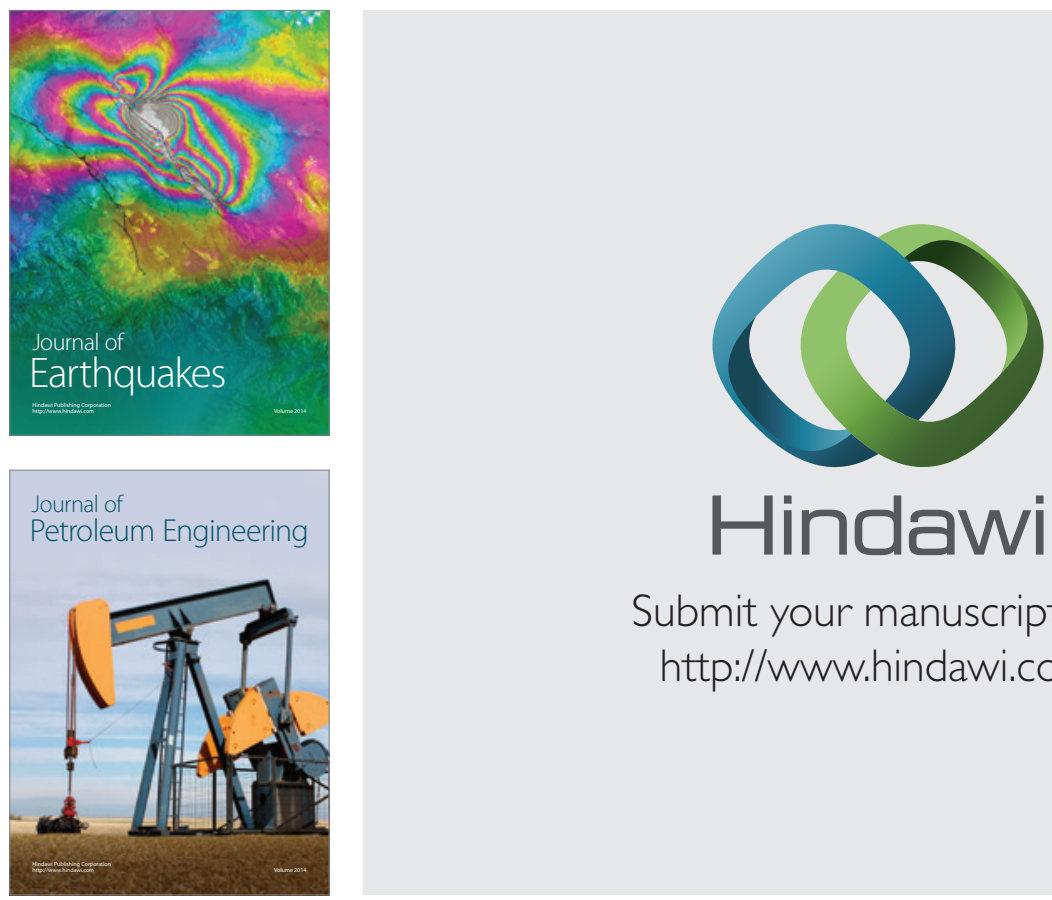

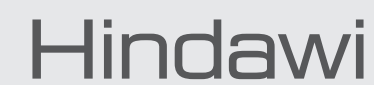

Submit your manuscripts at

http://www.hindawi.com
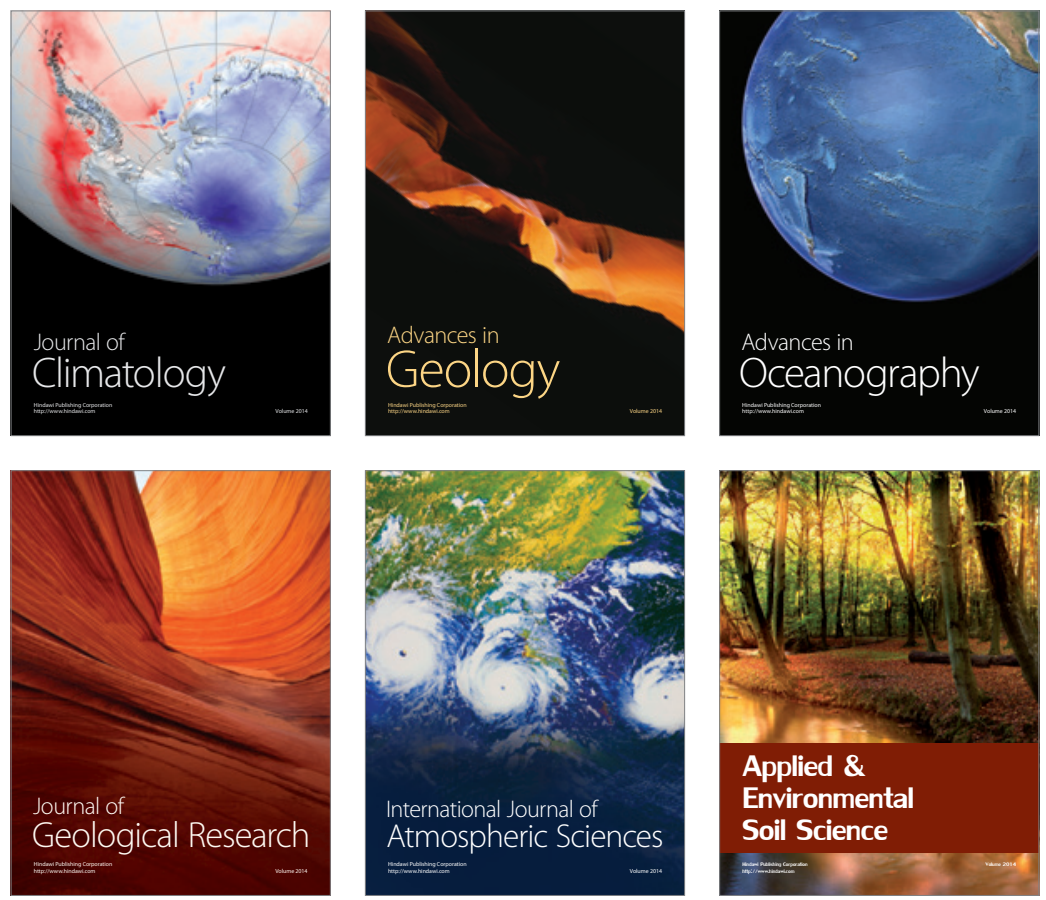
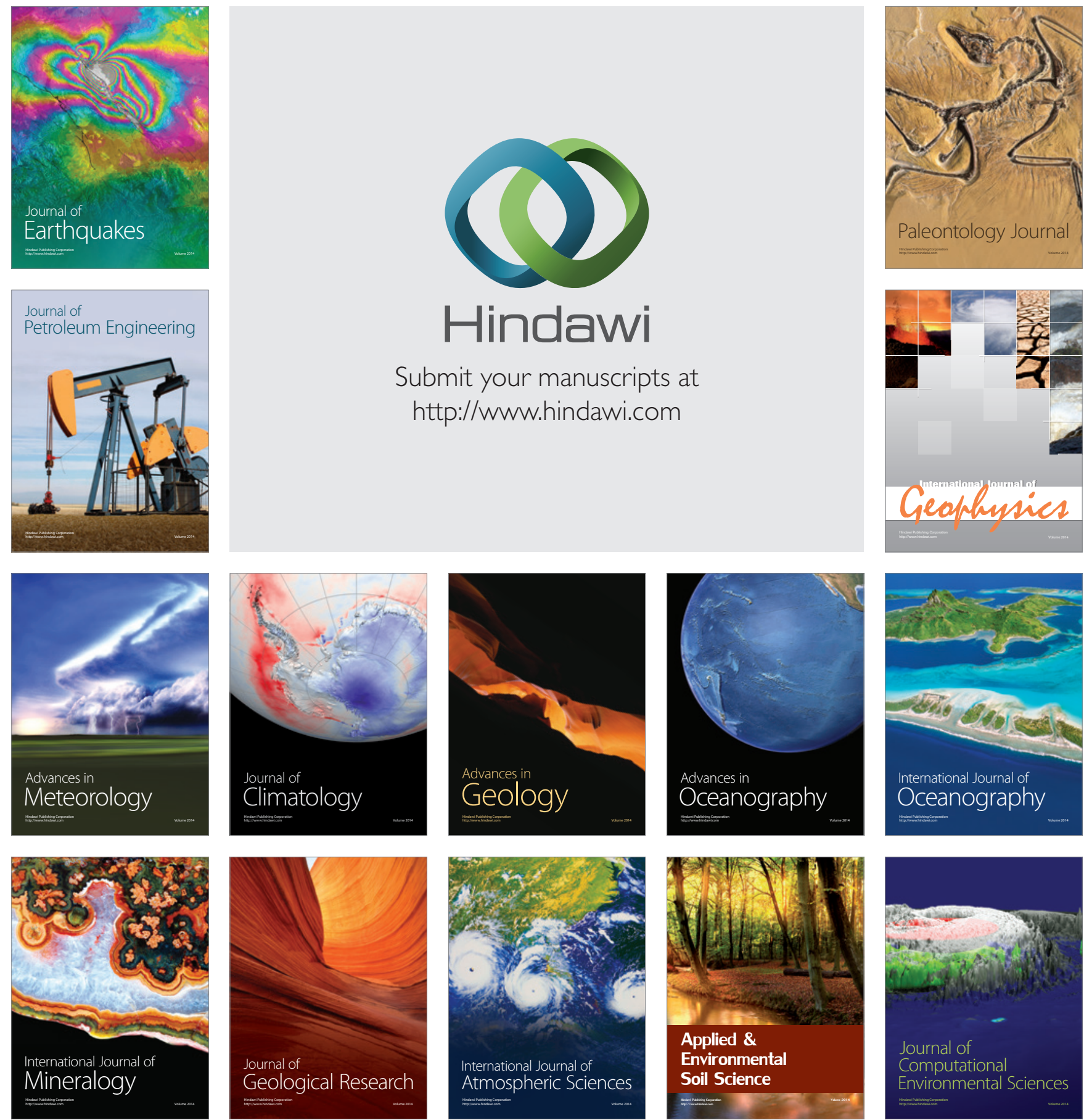